\title{
Use of artificial sediment to assess toxicity of chromium on Chironomus xanthus, Danio rerio and Poecilia reticulata
}

\author{
Utilização de sedimento artificial na avaliação da toxicidade \\ do cromo sobre Chironomus xanthus, Danio rerio e Poecilia reticulata
}

Aline Fernanda Campagna ${ }^{1}$, Beatriz Kawamura Rodrigues ${ }^{1}$, Roberta Corrêa Nogueirol ${ }^{2}$, Nelsy Fenerich Verani ${ }^{1}$, Evaldo Luiz Gaeta Espíndola ${ }^{3}$ and Luís Reynaldo Ferracciú Alleoni ${ }^{2}$

${ }^{1}$ Departamento de Hidrobiologia, Universidade Federal de São Carlos - UFSCar, Rod. Washington Luiz, Km 235, CEP 13565-905, São Carlos, SP, Brazil

e-mail: aline.campagna@gmail.com; beatriz_kr@yahoo.com.br; dnfv@ufscar.br

${ }^{2}$ Departamento de Ciência do Solo, Escola Superior de Agricultura Luiz de Queiroz, Universidade de São Paulo - USP, Av. Pádua Dias, 11, CEP 13418-900, Piracicaba, SP, Brazil e-mail: robertanogueirol@yahoo.com.br; alleoni@usp.br

${ }^{3}$ Núcleo de Estudos em Ecossistemas Aquáticos, Escola de Engenharia de São Carlos, Universidade de São Paulo - USP, Av. Trabalhados São-carlense, 400, CEP 13560-900, São Carlos, SP, Brazil e-mail: elgaeta@sc.usp.br

\begin{abstract}
Aim: Artificial sediments with simple formulations were used to assess the toxicity of $\mathrm{Cr}$ to $C$. xanthus, $D$. rerio and $P$. reticulata. Methods: The organisms were exposed to two sediment formulations: one without organic matter (S0) and one with $1 \%$ organic matter (SIII), both contaminated with $\mathrm{Cr}$ at concentrations of 90, 180, 360,720 and $1440 \mathrm{mg} / \mathrm{kg}$ for the assays with C.xanthus, and 375, 750, 1500 and 3000 $\mathrm{mg} / \mathrm{kg}$ for those with the two fish species. Chromium was obtained from the potassium dichromate $\left(\mathrm{K}_{2} \mathrm{Cr}_{2} \mathrm{O}_{7}\right)$. Results: The results of the acute toxicity tests demonstrated a reduction of up to four times in toxicity with the presence of OM, consisting of biodegradable detritus, even at the low concentration used (1\%), and that C.xanthus was most sensitive to the metal. The reduction in the chromium toxicity was indicated by the $\mathrm{LC}_{50}$ values, which were higher in SIII $(1234.43 \mathrm{mg} / \mathrm{kg} ; 2263.54 \mathrm{~m} / \mathrm{kg} ; 2244.48$ $\mathrm{mg} / \mathrm{kg})$ than in S0 $(340.56 \mathrm{mg} / \mathrm{kg} ; 1731.04 \mathrm{mg} / \mathrm{kg} ; 1733.55 \mathrm{mg} / \mathrm{kg})$ for C. xanthus, $D$. rerio and $P$. reticulata, respectively. Conclusions: Because of the repeatability of the results obtained, the artificial sediments with simple formulations were satisfactory to assess toxicity and can thus provide reliable results in ecotoxicological studies.
\end{abstract}

Keywords: Artificial sediment, Chromium, C. Xanthus, D. rerio, P. reticulata.

Resumo: Objetivo: Sedimentos artificiais com formulações simples foram utilizados para avaliar a toxicidade do $\mathrm{Cr}$ em $C$. xanthus, D. rerio e $P$. reticulata. Métodos: Os organismos foram expostos a duas formulaçôes: sem matéria orgânica (S0) e com $1 \%$ de matéria orgânica (SIII), contaminadas com Cr nas concentraçôes de 90; 180; 360; 720 e $1440 \mathrm{mg} / \mathrm{kg}$ para os ensaios com C. xanthus e 375; 750; 1500 e $3000 \mathrm{mg} / \mathrm{kg}$ para os ensaios com peixes. Resultados: Os resultados dos ensaios agudos demonstraram uma redução de até quatro vezes na toxicidade frente à presença de matéria orgânica detrital biodegradável (MO). C. xanthus apresentou maior sensibilidade ao metal em relação aos peixes. A reduçáo na toxicidade do $\mathrm{Cr}$ frente à presença de $\mathrm{MO}$ foi verificada nos valores de $\mathrm{CL}_{50}$, que estiveram mais elevados nos em SIII (C. xanthus $=1234,43$ $\mathrm{mg} / \mathrm{kg} ; D$. rerio $=2263,54 \mathrm{~m} / \mathrm{kg}$ e $P$. reticulata $=2244,48 \mathrm{mg} / \mathrm{kg})$ em relaçáo à $S 0(C$. xanthus $=340,56 \mathrm{mg} / \mathrm{kg} ;$ D. rerio $=1731,04 \mathrm{mg} / \mathrm{kg}$ e $P$. reticulata $=1733,55 \mathrm{mg} / \mathrm{kg}$ ). Conclusóes: Os sedimentos artificiais com formulaçóes simples foram satisfatórios na avaliação da toxicidade e asseguram resultados confráveis em estudos ecotoxicológicos.

Palavras-chave: Sedimento artificial, cromo, C. xanthus, D. rerio, P. reticulata.

\section{Introduction}

Sediment tends to accumulate trace metals in aquatic ecosystems (Soares et al., 1999). This characteristic is aggravated in water bodies that receive inflows of metals, either steadily or intermittently, and can result in severe effects on the benthic biota (Doig and Líber, 2006). Mediated by physical, chemical and biological processes, metals can return to the water column and thus pose a risk 
to the planktonic and nektonic communities, as well as triggering toxic effects in the other components of the food web (Adams, 1995).

Despite the importance of the sediment compartment, the assessment and quantification of the toxic potential of metals in natural sediments are still very difficult, since metals' physical and chemical characteristics are highly variable, as are the routes for absorption and elimination of these pollutants by aquatic organisms (Edwards and Simkiss, 2005). Therefore, the number of reported experiments with artificial sediments in the laboratory has been increasing (Naylor and Rodrigues, 1995; Clément and Cadier, 1998; Kemble et al., 1999; Ribeiro et al., 1999; Verrhiest et al., 2002; Feiler et al., 2004; Roman et al., 2007). These studies permit evaluating the effects of various types of pollutants on aquatic organisms under pre-established conditions.

There are many advantages of using artificial sediment, among them: (i) the possibility of exercising rigorous control, with well-known characteristics and properties (size and proportion of particles, chemically specific surfaces), to assess and predict how natural sediments will react to contact with various types of pollutants; (ii) the absence of native microfauna and contaminants, to enable good reproducibility; (iii) the possibility of supporting the survival and growth of various organisms (plants and animals); (iv) the possibility of comparison with the results of other laboratory tests as well as field tests with natural sediments; (v) the ability to be stored without great difficulties (Suedel and Rodgers, 1994); and (vi) the ability to provide information on the behavior of substances individually or in complex mixtures in function of the substrate composition.

In a previous study we tested simple formulations of artificial sediments, aiming to reduce the costs of obtaining the fractions (by avoiding the need for sample collection in the field and storage before use in the laboratory) and to facilitate testing because of the ease of preparing the sediments. Our results demonstrated that the formulations prepared were satisfactory for use in ecotoxicological tests, since they were not found significant ecotoxicological effects on survival, growth, and morphology of gills ments and bioaccumulation of metals in benthic and nektonic species of this study. Thus, the present study aimed to test the feasibility of these formulations in assessing the ecotoxicity of a metal widely studied, chromium. In this way, the results could be demonstrated widely known to the present study, thereby, increasing the reliability in using the artificial sediment.

Chromium $(\mathrm{Cr})$ is a metal widely utilized for various purposes, such as metallurgy, textiles (dyes), leather tanning, wood preservation and fertilizers (HSDB 2000, cited in Silva and Pedrozo, 2001). Its toxicity to aquatic organisms has been amply demonstrated over many decades (Stevens and Chapman, 1984; Dave et al., 1987; Jop et al., 1987; Villaescusa et al., 1997; Ceurdassier et al., 2000; Choi and Roche, 2004; Svecevicius, 2006, 2007; Vedamanikam and Shazilli, 2008). In natural systems, $\mathrm{Cr}$ is present in two oxidative states, $\mathrm{Cr}^{3+}$ (trivalent) and $\mathrm{Cr}^{6+}$ (hexavalent), each with different geochemical and toxicological properties. $\mathrm{Cr}^{6+}$ is highly oxidizable and unstable in reduced environments and anoxic sediments, and is thus highly soluble and toxic (De Laune et al., 1998). In contrast, $\mathrm{Cr}^{3+}$ has low solubility and is less toxic (Wang et al., 2001).

The choice of the test organisms was based on the possible exposure routes to the organisms from the addition of chromium to the sediments, namely direct exposure (affecting benthic organisms) and indirect exposure through partition to the water column (affecting nektonic organisms). Two nektonic organisms were chosen, to compare the responses of a species native to tropical ecosystems (Poecilia reticulata) and an exotic species (Danio rerio), and the benthic organisms was Chironomus xanthus.

Therefore, the aim of this study was to asses and confirms the potential use of a simple artificial sediment formulation (sand, clay and organic matter) in acute toxicity assays with chromium using test organisms from different trophic levels.

\section{Material and Methods}

\subsection{Artificial sediments}

The artificial sediments were formulated containing fractions of large-grained sand (about $90 \%)$, kaolinite clay (10\%), without organic matter (S0) and $1 \%$ of organic matter (SIII). The percentages of the fractions used were determined based on the average concentration found in natural sediment samples from water bodies in the upper Jacaré-Guaçu watershed, located in São Paulo, Brazil

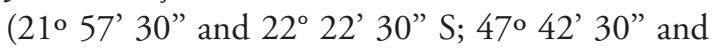
$\left.48^{\circ} 05^{\prime} 30^{\prime \prime} \mathrm{W}\right)$.

The sand was acquired from a company specialized in materials for water filtering (Mineração Jundu Ltda.) and had grain size between 0.4 and 
$1.0 \mathrm{~mm}$, without organic matter and contaminants, certified under no. 820-1. The kaolinite clay was also obtained commercially (Labsynth), with special characteristics for use in cosmetics and pharmaceutical products, thus being free from contaminants (certification no. 156610).

The organic matter was obtained from the aquatic macrophyte species Scirpus cubensis, which was collected near the Jataí Ecological Station, located beside Óleo Lake in the municipality of Luiz Antônio, São Paulo state, $\left(21^{\circ} 35^{\prime}\right.$ 14” S and $\left.47^{\circ} 50^{\prime} 34^{\prime \prime} \mathrm{W}\right)$. This lake has a low level of human interference (Rocha and Bianchini, personal communication). After being collected, the macrophyte material was dried at room temperature and then in a hot chamber $\left(40{ }^{\circ} \mathrm{C}\right)$, ground and then pulverized to obtain particles smaller than $1.0 \mathrm{~mm}$ in diameter (OECD, 2004). The analysis of the metals in the macrophyte extracts was performed according to the method described in Silverio et al., 2006.

The dry fractions of artificial sediment were mixed manually in distilled water only (control and S0) or with distilled water and solutions of chromium (SIII) in volumes established previously in experiments of the sediments' retention capacity (60\%) (Embrapa, 2000). After being moistened, the sediments were maintained in a darkened room at room temperature $\left(25 \pm 2{ }^{\circ} \mathrm{C}\right)$ for a period of 24 hours, the minimum time necessary to stabilize the substrate (OECD, 2004). Then reconstituted water was carefully added in the proportion of $1: 4$ (sediment/water) and the sediment formulations were again kept for 24 hours under the same conditions described above.

\subsection{Maintenance of the test organisms}

The specimens of C. xanthus (Chironomidae, Diptera) were obtained from cultures maintained in the Ecotoxicology Laboratory of the Department of Ecology and Evolutionary Biology (DEBE), of São Carlos Federal University, São Paulo state, Brazil. The organisms were reared according to the recommendations of Fonseca and Rocha (2004), being fed with algae at a concentration of $10^{5}$ cells/ $\mathrm{mL}$ (clorofícea Pseudokirchneriella subcapitata) only on the first day and the commercial fish food Tetrafin ${ }^{\circledR}$ in the proportion of $0.04 \mathrm{mg} / \mathrm{mL}$ on the other days. Sensitivity tests were conducted with the C. xanthus specimens to potassium chloride (KCl) following the recommendations of Fonseca and Rocha (2004).
The juvenile D. rerio (Cypriniformes, Cyprinidae) and P. reticulata (Cyprinodontiformes, Poecillidae) specimens were obtained commercially and kept in the laboratory for 15 days for acclimation before being exposed in the toxicity tests. The maintenance, feeding and sensitivity tests to $\mathrm{K}_{2} \mathrm{Cr}_{2} \mathrm{O}_{7}$ (potassium dichromate P.A. ACS 100\%, Synth) were carried out as recommended by the Brazilian Association of Technical Standards (ABNT, 2004).

\subsection{Acute toxicity tests}

The chromium solutions were prepared using sodium dichromate $\left(\mathrm{K}_{2} \mathrm{Cr}_{2} \mathrm{O}_{7}\right)$. The $\mathrm{Cr}$ concentrations used in the acute toxicity tests with C. xanthus $(90 \mathrm{mg} / \mathrm{kg}, 180 \mathrm{mg} / \mathrm{kg}, 360 \mathrm{mg} / \mathrm{kg}$, $720 \mathrm{mg} / \mathrm{kg}$ and $1440 \mathrm{mg} / \mathrm{kg}$ ) and with the two fish species $(375 \mathrm{mg} / \mathrm{kg}, 750 \mathrm{mg} / \mathrm{kg}, 1500 \mathrm{mg} / \mathrm{kg}$ and $3000 \mathrm{mg} / \mathrm{kg}$ ) were ascertained by preliminary tests. The test solutions were added to the different artificial sediments to compose two experimental treatments: i) addition of the contaminant with organic matter ( $\mathrm{S} 0$ ); and ii) addition of the contaminant to the sediment without organic matter (SIII). Each treatment was repeated three times.

The assays with $C$. xanthus were carried out according to the method described by Fonseca and Rocha (2004), by exposing six specimens of the 4th instar in samples of sediment/water in a proportion of 1:4. Each replication was in a disposable plastic cup with capacity of $250 \mathrm{~mL}$, containing $60 \mathrm{~g}$ of sediment and $240 \mathrm{~mL}$ of water. There were three replications for each treatment, for a total of 18 test organisms. The tests lasted 96 hours. A control group (B), with sediment consisting only of the sand used to rear the specimens, was included in the tests. The mortality of the organisms was determined with the aid of a fine net and magnifying glass. The specimens were only fed on the first day of the test, in the same proportions used during their rearing.

For $D$. rerio and $P$. reticulata, the tests were conducted according to the standards of the ABNT (2004), whereby five organisms were exposed in sediment/water samples in the proportion of 1:4 (Burton and MacPherson, 1994). Each replication was carried out in a disposable plastic recipient with capacity of $1000 \mathrm{~mL}$, containing $100 \mathrm{~g}$ of sediment and $400 \mathrm{~mL}$ of water. There were two replications for each treatment, for a total of 10 test organisms. These tests lasted 48 hours. There was also a control group (C) with only reconstituted water. During the experiments, the responses of the fish specimens only exposed with sand (A) and in the control group 
(C) did not show significant differences in the acute and chronic effects (according to Fisher's exact test; $p>0,05$ and the Kruskall-Wallis test; $p>0,05$, respectively), so it was decided only to continue with the $\mathrm{C}$ group as a control in these tests. The mortality was determined by counting the dead specimens and the organisms were not fed during the testing period.

The following parameters were measured at the start and end of the experiments with all the species tested: $\mathrm{pH}$ ( $\mathrm{pH}$ meter), hardness (titulometry) and conductivity (conductivity meter). During the tests, the temperature $\left(25 \pm 2{ }^{\circ} \mathrm{C}\right)$ and photoperiod (12h:12h; light:dark) were controlled (Fonseca and Rocha, 2004; ABNT, 2004).

\subsection{Physical and chemical analyses}

In all the tests, the total content of chromium in the water (APHA, 1995) and its bioavailable $\mathrm{Cr}$ in the sediments (as described by Silverio et al., 2006) were determined by taking samples at the start and end of the tests, using 20-mL disposable syringes to avoid resuspension of the sediment. For this purpose, three replicas of the experiments were added.

\subsection{Sequential extraction analysis}

The sequential extraction analysis was performed in sediments $\mathrm{SO}$ and $\mathrm{SIII}$ to assist in the interpretation of chromium bioavailability to aquatic organisms, using some fractions of the method adapted from Silveira et al., (2006) for tropical soils because there was no breakdown of oxides as described by these authors. The fractions were: (i) exchangeable (F1), (ii) connected to carbonates (F2) (due to the high $\mathrm{pH}$ of the samples), (iii) bound to organic matter (F3), (iv) bound with iron oxides, $\mathrm{Al}$ and $\mathrm{Mn}$ (F4) and (v) residual (F5). To perform extraction was sequentially weighed equivalent to $1.0 \mathrm{~g}$ of dry material (sediment artificial) sieved to 100 mesh and added to polycarbonate centrifuge tubes. The samples were equilibrated for $2 \mathrm{~h}$ with $15 \mathrm{ml} 0.1 \mathrm{M}$ $\mathrm{CaCl}_{2}$ (F1). Was added $30 \mathrm{~mL}$ of $1 \mathrm{M} \mathrm{NaOAc}(\mathrm{pH}$ 5) with stirring horizontal shaker for $5 \mathrm{~h}$ at ambient temperature for extraction of F2. To obtain F3 samples were extracted with $5 \mathrm{ml}$ of $5 \% \mathrm{NaOCl} \mathrm{pH}$ adjusted to 8.5. The centrifuge tubes were placed in a water bath at $90{ }^{\circ} \mathrm{C}$ for $30 \mathrm{~min}$. The samples were centrifuged, filtered, and the supernatant was collected. This procedure was repeated four times. In no $\mathrm{F} 4$ fractions of oxides and this fraction was obtained by use of $0.2 \mathrm{M}$ ammonium oxalate $+0.2 \mathrm{M}$ oxalic acid $+0.1 \mathrm{M}$ ascorbic acid ( $\mathrm{pH}$ 3) (Schwertmann, 1964). The samples were mixed with $40 \mathrm{~mL}$ of extraction solution in a water bath at $90^{\circ} \mathrm{C}$ for $30 \mathrm{~min}$. F5 was obtained after a total digestion with $\mathrm{HF}+\mathrm{HNO} 3+$ ultrapure water in a microwave oven, according to EPA Method 3052 (EPA, 1996).

Between each successive extraction sample was suspended with $5.0 \mathrm{ml}$ of $0.1 \mathrm{M} \mathrm{NaCl}$, to displace the previous solution that may have remained in the tube, and to reduce the resorption of metal (Ahnstrom and Parker, 1999). The metals were determined in each fraction by atomic absorption spectrophotometry with graphite furnace (Model Spectraa 220, Varian), and the index was calculated coating used as a criterion for control of the results the maximum tolerable error equal to $\pm 20 \%$, and: Recovery $(\%)=(\mathrm{S}$ metal contents in the fractions / total content) x 100. The degree of recovery $(100 \pm 20 \%)$ was used as a criterion of quality control analyzes (Silveira et al., 2008). Total concentrations were determined according to EPA Method 3052 with microwave digestion with $\mathrm{HNO}_{3}+\mathrm{HF}+$ ultrapure water (EPA, 1996).

\subsection{Evaluation of the results}

The mortality were expressed as LC(I) $50 ; 96 \mathrm{~h}$ for C. xanthus and LC(I) 50; 48h for the two fish species, obtained by using the trimmed SpearmanKarber method (Hamilton et al., 1977).

\section{Results}

\subsection{C. xanthus}

In the tests with $\mathrm{S} 0$ the average $\mathrm{LC}_{50} ; 96 \mathrm{~h}$ was $340.56 \mathrm{mg} / \mathrm{kg}$, with a standard deviation of $32.7 \mathrm{mg} / \mathrm{kg}$ and coefficient of variation of $9.62 \%$ (Figure 1). In the tests with SIII it was possible to calculate the $\mathrm{LC}_{50} ; 96 \mathrm{~h}$ in only one definitive test, with a value of $1234.43 \mathrm{mg} / \mathrm{kg}$ of chromium, almost four times the figure for the average $\mathrm{LC}_{50} ; 96 \mathrm{~h}$ with S0 (Figure 1). In the other definitive tests it was not possible to calculate the $\mathrm{LC}_{50} ; 96 \mathrm{~h}$ because of the low mortality at the last concentration, suggesting $\mathrm{LC}_{50} ; 96 \mathrm{~h}$ values above $1440 \mathrm{mg} / \mathrm{kg}$ of chromium for this substrate (Figure 1).

The analysis of the chromium concentrations in the water showed levels two times higher after 96 hours in the tests with both S0 and SIII. The concentrations in the water with $\mathrm{S} 0$ during the tests ranged from $2.24 \mathrm{mg} / \mathrm{L}(90 \mathrm{mg} / \mathrm{kg})$ to $67.44 \mathrm{mg} / \mathrm{L}$ $(1440 \mathrm{mg} / \mathrm{kg})$, while for SIII the figures were between $0.25 \mathrm{mg} / \mathrm{L}(90 \mathrm{mg} / \mathrm{kg})$ and $23.93 \mathrm{mg} / \mathrm{L}(1440 \mathrm{mg} /$ $\mathrm{kg})$. Therefore, the chromium concentrations in the water with sediment $\mathrm{S} 0$ were five to 20 times greater than in the water with sediment SIII (Figure 2).

The determination of the chromium concentration at the start $(0 \mathrm{~h})$ and end of the tests 

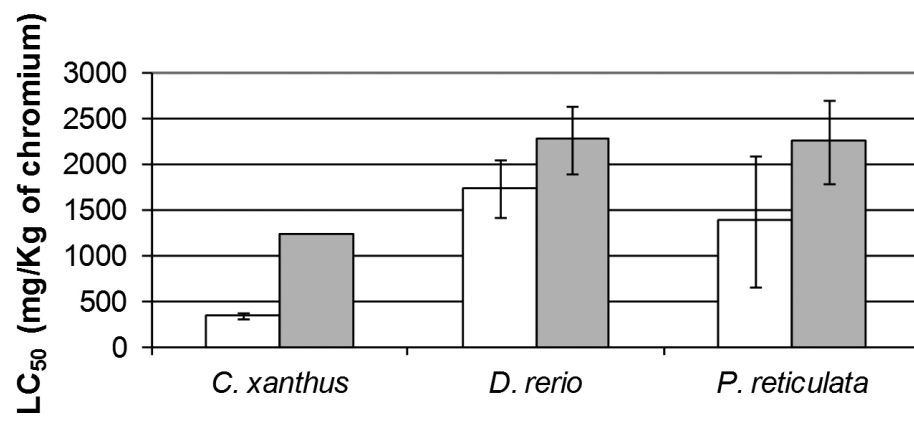

¿SO पSIII

Figure 1. Mean LC50 values and standard deviations $(\wedge)$ in the acute toxicity tests with artificial sediments (S0 and SIII) utilizing C. xanthus, D. rerio and P. reticulata as test organisms.

Oh

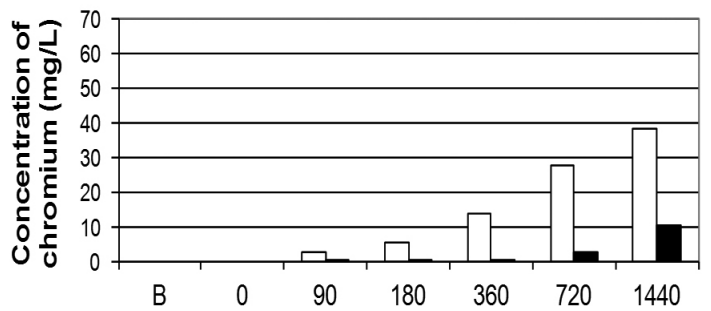

QSO $\mathrm{QSII}$
$96 \mathrm{~h}$

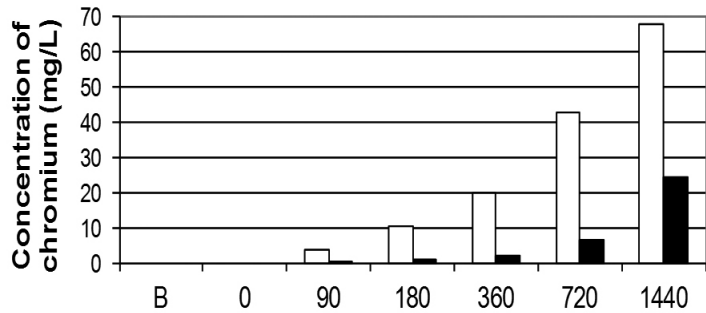

QSO $\mathbf{m S I I I}$

Figure 2. Chromium concentration in the water at the beginning (0h) and end (96h) of the tests with artificial sediment in Chironomus xanthus with (SIII) and without organic matter (S0). B: Controle (treatment with sand without contamination by chromium).

(96h) in the sediments showed higher levels at the start in both S0 and SIII. The concentrations in S0 during the tests varied from $2.50 \mathrm{mg} / \mathrm{kg}$ $(180 \mathrm{mg} / \mathrm{kg})$ to $233.12 \mathrm{mg} / \mathrm{kg}(1440 \mathrm{mg} / \mathrm{kg})$, while in SIII these numbers ranged from $1.52 \mathrm{mg} / \mathrm{kg}$ $(1440 \mathrm{mg} / \mathrm{kg}$ at $96 \mathrm{~h})$ to $55.57 \mathrm{mg} / \mathrm{kg}(1440 \mathrm{mg} / \mathrm{kg}$ at $0 \mathrm{~h})$. Therefore, for the sediments the chromium concentration at the start of the tests was about five times higher in S0 than in SIII (Figure 3), while after $96 \mathrm{~h}$ the concentration was about two times higher in SIII than in S0, except at concentrations of $1440 \mathrm{mg} / \mathrm{kg}$ and $90 \mathrm{mg} / \mathrm{kg}$, where the chromium levels were respectively about 15 and five times higher in SIII (Figure 3).

\subsection{D. rerio and P. reticulata}

The average $\mathrm{LC}_{50} 48 \mathrm{~h}$ in the tests with $D$. rerio with S0 was $1731.04 \mathrm{mg} / \mathrm{kg}$, with a standard deviation of $322.02 \mathrm{mg} / \mathrm{kg}$ and a coefficient of variation of $18.60 \%$ (Figure 1 ). In the test with SIII, it was only possible to calculate the $\mathrm{LC}_{50 ;} 48 \mathrm{~h}$ in two definitive tests $(2004.40 \mathrm{mg} / \mathrm{kg}$ and $2522.69 \mathrm{mg} / \mathrm{kg}$ ). Both of these values were higher as the average $\mathrm{LC}_{50} 48 \mathrm{~h}$ determined in the tests with $\mathrm{S} 0$. In the tests with $P$. reticulata utilizing S0, the average $\mathrm{LC}_{50} 48 \mathrm{~h}$ was $1733.55 \mathrm{mg} / \mathrm{kg}$ and the standard deviation was $710.44 \mathrm{mg} / \mathrm{kg}$, while with SIII the average $\mathrm{LC}_{50}, 48 \mathrm{~h}$ was $2244.48 \mathrm{mg} / \mathrm{kg}$ with a standard deviation of $453.35 \mathrm{mg} / \mathrm{kg}$, higher than for S0 (Figure 1).

The determination of the chromium concentrations in the water in the tests with the two fish species showed that they were higher after $48 \mathrm{~h}$ except for the initial concentrations of $3000 \mathrm{mg} / \mathrm{kg}$ (S0) and 375 and $750 \mathrm{mg} / \mathrm{kg}$ (SIII). In the tests with $\mathrm{S} 0$, the chromium concentrations ranged from $2.06 \mathrm{mg} / \mathrm{L}(375 \mathrm{mg} / \mathrm{kg})$ to $5.25 \mathrm{mg} / \mathrm{L}$ $(3000 \mathrm{mg} / \mathrm{kg})$, while in the tests with SIII these values were $2.52 \mathrm{mg} / \mathrm{L}(375 \mathrm{mg} / \mathrm{kg})$ and $99.08 \mathrm{mg} / \mathrm{L}$ $(3000 \mathrm{mg} / \mathrm{kg})$. Therefore, the chromium concentrations were from 2 to 20 times higher in the water with SIII than with S0 (Figure 4).

For the sediments, the analysis of the chromium levels at the start $(0 \mathrm{~h})$ and end (48h) of the tests showed higher metal concentrations at the start in the tests with S0 (3 to 7 times) and with SIII 
Oh

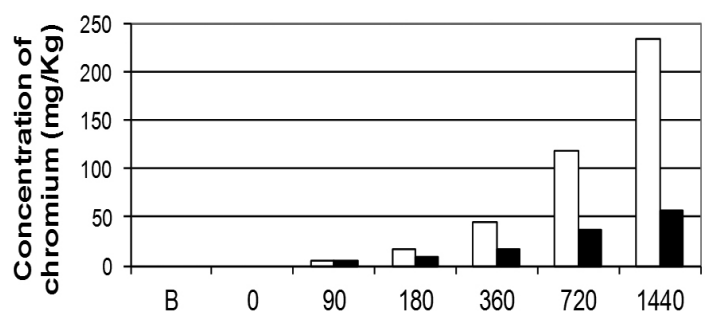

QSO МSIII
$96 \mathrm{~h}$

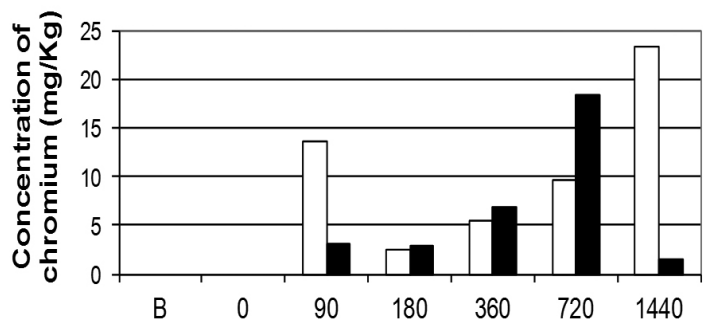

QSO 【SIII

Figure 3. Chromium concentration in the sediment at the beginning $(0 \mathrm{~h})$ and end $(96 \mathrm{~h})$ of the tests with artificial sediment in Chironomus xanthus with (SIII) and without organic matter (S0). B: control (treatment with sand without contamination by chromium).

oh

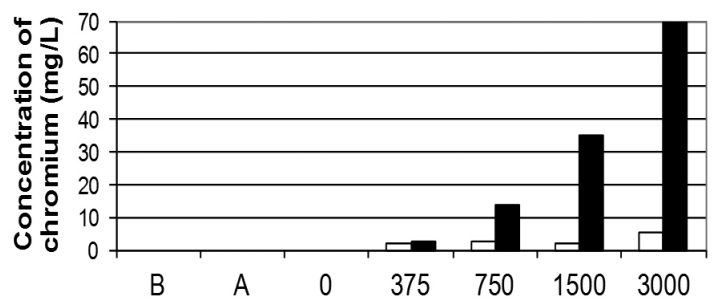

QSO ISIII
$48 \mathrm{~h}$

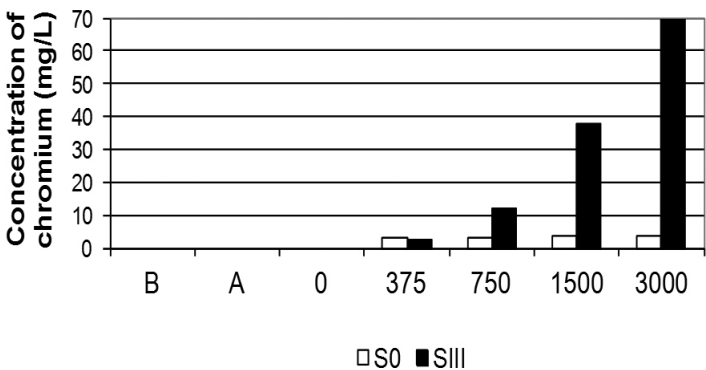

Figure 4. Chromium concentration in the water at the beginning $(0 \mathrm{~h})$ and end (486h) of the tests with artificial sediment in D. rerio and P. reticulata with (SIII) and without organic matter (S0). A: treatment with sand without contamination by chromium; B: blank (reconstituted water).

(some three times), except for the concentration of $3000 \mathrm{mg} / \mathrm{kg}$ (SIII). The chromium concentrations in S0 during the tests were between $16.25 \mathrm{mg} / \mathrm{kg}$ $(750 \mathrm{mg} / \mathrm{kg})$ and $289.50 \mathrm{mg} / \mathrm{kg}(3000 \mathrm{mg} / \mathrm{kg})$, while in SIII these levels were between $18.5 \mathrm{mg} / \mathrm{kg}$ $(3000 \mathrm{mg} / \mathrm{kg})$ and $177.25 \mathrm{mg} / \mathrm{kg}(1500 \mathrm{mg} / \mathrm{kg})$ (Figure 5). Comparison of the artificial sediments thus showed that at the start of the experiment, the chromium levels were around two to 15 times higher in S0 than in SIII, while at the end (48h), this situation was no longer true, since for the majority of the fortified concentrations, the level in SIII was only around two times higher than that in S0 (Figure 5).

For all three species, the average $\mathrm{LC}_{50}$ was lower in the tests with $\mathrm{S} 0$, with a greater difference for the tests with $C$. xanthus. This species was more sensitive, with low $\mathrm{LC}_{50}$ values for both sediments (S0 and SIII), while $D$. rerio and $P$. reticulata presented similar $\mathrm{LC}_{50}$ values and sensitivity (Figure 1).

\subsection{Sequential extraction analysis}

Most of the chromium was in the residual fraction treatments S0 and SIII (up to almost $80 \%$ of the total content of the element in treating S0). In the treatment S0 distribution of $\mathrm{Cr}$ was in descending order: residual $>$ oxides $>$ $\mathrm{MO}>$ carbonate> exchangeable (Figure 6). In the treatment S0 only $21.3 \%$ of $\mathrm{Cr}$ was distributed in fractions considered potentially available, while $59.9 \%$ in the treatment SIII this element was these fractions (Figure 6). In the treatment of the metal fraction SIII linked to organic matter was more significant than in the treatment $\mathrm{S} 0$, which was expected since this treatment is the addition of organic compound in its formulation and the element affinity for organic compounds.

\section{Discussion}

The results of the toxicity tests indicated that the mean $\mathrm{LC}_{50}$ for all the test organisms was two to four times higher in SIII. The benthic species 
Oh

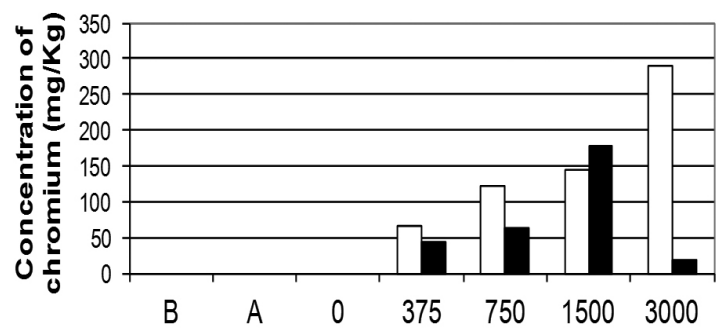

QSO ISIII
$48 \mathrm{~h}$

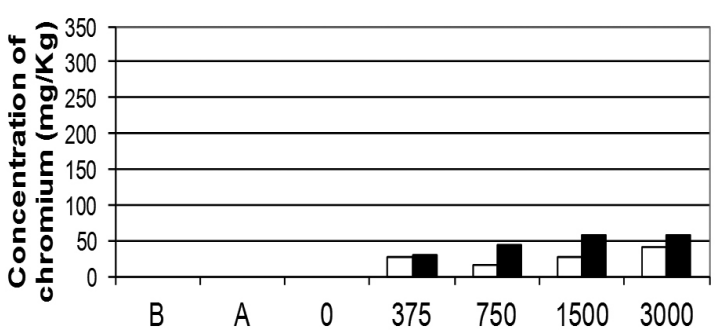

QSO घSIII

Figure 5. Chromium concentration in the sediment at the beginning $(0 \mathrm{~h})$ and end $(48 \mathrm{~h})$ of the tests with artificial sediment in D. rerio and P. reticulata with (SIII) and without organic matter (S0). A: treatment with sand without contamination by chromium; B: Blank (reconstituted water).

\section{- exchangeable $\square$ carbonates $\square \mathrm{OM} \mathbb{Q}$ oxides $\square$ residual}

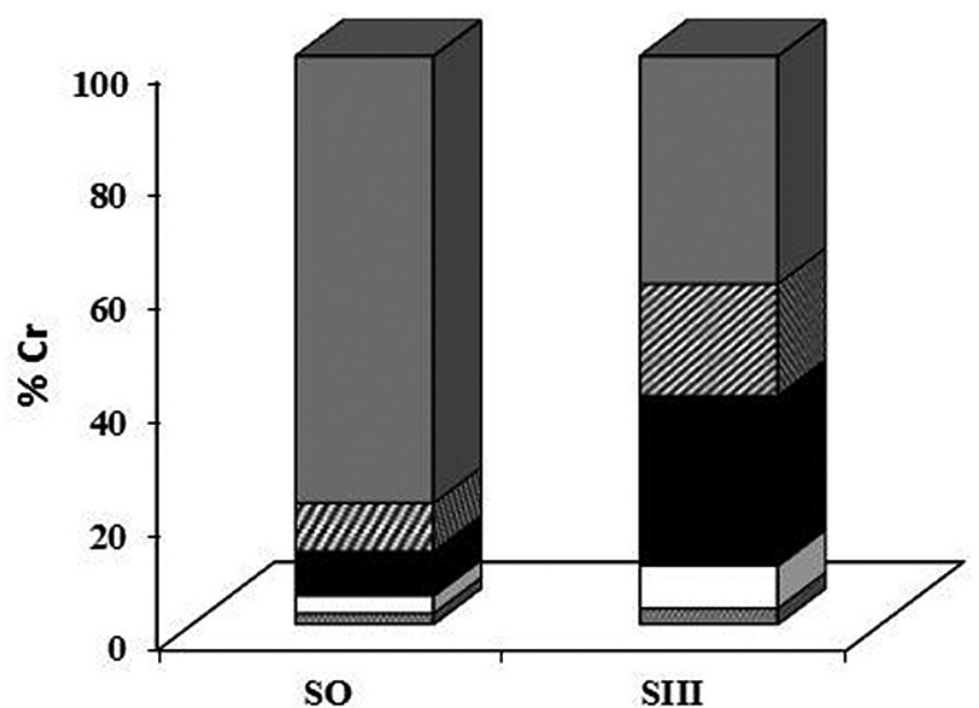

Figure 6. Percent distribution of chromium (\%) in sequential extraction fractions for each treatment.

(C. xanthus) was more sensitive than the two nektonic species (D. rerio and $P$. reticulata), with an average $\mathrm{LC}_{50}$ figure only about one-fifth as high. The sensitivity was similar between the two nektonic species due to the habitat and the animal group.

The average $\mathrm{LC}_{50} ; 48 \mathrm{~h}$ values in the tests with chromium dissolved in the water with sediments SIII and S0 for D. rerio $(2263.54 \mathrm{mg} / \mathrm{kg} ; 1731.04 \mathrm{mg} /$ $\mathrm{kg})$ and $P$. reticulata $(2244,48 \mathrm{mg} / \mathrm{kg} ; 1377,55 \mathrm{mg} /$ $\mathrm{kg}$ ) showed that mortality occurred at respective chromium concentrations of approximately 70.0 $\mathrm{mg} / \mathrm{L}$ and $3.5 \mathrm{mg} / \mathrm{L}$ for both two species. Therefore, the toxicity to chromium in the water was reduced nearly 20 times with SIII in comparison with S0.
There were higher concentrations of chromium dissolved in the water in the tests with SIII both at the start and end of the testing. The chromium concentrations in the water were directly related to the concentrations added to the sediments and also to the toxicity.

The lower toxicity in the samples with the SIII in relation to those with S0, despite the higher levels of chromium dissolved in the water with the former sediment, may have occurred because of the instability of the chemical species regarding dissolved organic carbon (DOC). $\mathrm{Cr}^{6+}$ (highly toxic and oxidizable) is easily reduced to $\mathrm{Cr}^{3+}$ (lower toxicity) in the presence of DOC and 
humic substances (HS) (Skogerboe and Wilson, 1981; Wittbrodt and Palmer, 1995). Besides this, the organic matter (OM) and byproducts of its degradation can complex metals and make them unavailable to the organisms. In light of the high DOC concentration in SIII $(18.0 \mathrm{mg} / \mathrm{L})$, the chromium in the water could be in unavailable form (complexed with OM) or reduced form (less toxic), causing lower toxicity. However, in the present study we did not evaluate the chemical species of chromium in the experiments.

Various researchers have demonstrated the influence of DOC on the toxicity of metals. Bringolf et al. (2006) evaluated the effect of dissolved OM on the acute toxicity of zinc to Pimephales promelas larvae. They found that a minimum concentration of $11.0 \mathrm{mg} / \mathrm{L}$ of DOC was necessary to reduce the $\mathrm{LC}_{50}$; $96 \mathrm{~h}$ of zinc, and this was positively correlated with the DOC concentrations. Our results here corroborate those findings.

Brooks et al. (2007) assessed the influence of photodegraded dissolved OM on the toxicity of copper to Pimephales promelas larvae and observed that the mortality was higher in the treatments with lower density of binding sites between $\mathrm{Cu}$ and DOC. Brooks et al. (2007) noted that the photochemical changes of the DOC in the bonds increased the concentration of free copper ions from 31 to $85 \%$, as a result of the reduced density ot the binding sites between the elements, triggering greater toxicity. Nakayasu et al. (1999) carried out a comparative study of reduction of $\mathrm{Cr}^{6+}$ in the presence of $\mathrm{HS}$ and their precursors and found different results between the compounds with high molecular weight (HS and SF) and those with low molecular weight (GA and TA). The authors found that the kinetics of reduction of $\mathrm{Cr}^{6+}$ to $\mathrm{Cr}^{3+}$ was two times higher for compounds with low molecular weight, with the reduction capacity in the following order: $\mathrm{SH}$ and $\mathrm{SF}<\mathrm{TA}<\mathrm{GA}$.

The sequential extraction analysis confirmed the considerations described, since the same results demonstrated the highest bioavailability of chromium in sediments S0. According to Alomary and Belhadj (2007) the bioavailability of an element decreases with decreasing exchangeable for residual phases. The authors conducted a study in order to investigate the distribution of metals in sediment fractions of the Mediterranean Sea, and found that most metals predominate in F5 and smaller percentages are related to F1 and F2. As to the chromium percentages were found in the following order: $\mathrm{F} 2<\mathrm{F} 1<\mathrm{F} 3<\mathrm{F} 4<\mathrm{F} 5$, with about $5 \%$ in $\mathrm{F} 1 ; 5 \%$ by $\mathrm{F} 2 ; 8 \%$ by $\mathrm{F} 3 ; 25 \%$ and $55 \%$ by $\mathrm{F} 4$ and F5. Although the values are related to marine sediments, results are similar to those observed in the present study.

Our results detected the distribution of chromium in order $\mathrm{F} 1<\mathrm{F} 2<\mathrm{F} 3<\mathrm{F} 4<\mathrm{F} 5$ in $\mathrm{S} 0$ and $\mathrm{F} 1<\mathrm{F} 2<\mathrm{F} 4<\mathrm{F} 3<\mathrm{F} 5$ in SIII. The values detected in $\mathrm{F} 1$ (1.9\% and $2.8 \%$ for S0 in SIII) show higher bioavailability in S0. In the SIII chrome on the F3 was $29.9 \%$ while in S0 this figure was $7.8 \%$. This fraction is represented by the portion that is not easily released to the environment, since the metal is bonded to the crystal structures of minerals from the sediment (Savvides et al., 1995). Thus, the percentages of chromium attached to this fraction, as verified in this study $(78.7 \%$ and $40.1 \%$ for S0 in SIII), suggests that in the absence of $\mathrm{MO}$ and therefore fewer binding sites for complexation, chromium binds to mineral components of sediments in greater proportion. In fact, the fraction $\mathrm{F} 3$ in SIII was second in descending order presented above, other than S0. Accordingly, Förstner (1987) reported the existence of a time-dependent intensity adsorption compounds and suggested that the adsorption sites high energy (less numerous) are filled first, and become limiting in few, and that all the energy of the sediment decreases as these sites are filled less energy.

Another possible explanation for the higher chromium levels in the water in the tests with sediments containing organic matter is the characteristic of the sediment, i.e., although the sand fraction was high $(-80 \%)$, the height of the sediment in the test recipients was under $3.0 \mathrm{~cm}$. These conditions could have favored partition of the chromium from the sediments to the water at low OM concentrations (1\%) (Eimers et al., 2002).

The chromium concentrations in the water in the tests with S0 were lower than in the tests with SIII. In this case the toxicity found at low chromium concentrations is likely mainly related to the metal's tendency to remain in hexavalent form (highly toxic and oxidizable) in S0 (Nakayasu et al., 1999). The cation exchange capacity of kaolinite clay (30-150 $\mathrm{mmol}_{\mathrm{c}} / \mathrm{kg}$ ) means there are additional binding sites, mainly of oxides of $\mathrm{Fe}$ and $\mathrm{Al}$, perhaps mediating the partition of the chromium in S0 (Eimers et al., 2002).

The bioavailability of metals is related to various factors, such as the characteristics of the contaminant, chemical composition of the sediment, time of adsorption with the metal, 
temperature, $\mathrm{pH}$, redox potential and behavior and physiology of the organisms (feeding habit, capacity to metabolize compounds, among others) (Baudo et al., 1990). Therefore, relating the bioavailability of chromium only to the MO content can produce an unrealistic estimate.

In the present study we found an average $\mathrm{LC}_{50} ; 48 \mathrm{~h}$ (in relation to the concentration dissolved in the test water) of $86.04 \pm 48.71 \mathrm{mg} / \mathrm{L}$ of chromium for $P$. reticulata. For $D$. rerio this value was found to be $42.33 \pm 15.34 \mathrm{mg} / \mathrm{L}$ (Nakagome et al., 2007). These levels are near those found for the SIII sediments $(70.0 \mathrm{mg} / \mathrm{L})$, but very different than for the $\mathrm{S} 0$ sediments $(3.5 \mathrm{mg} / \mathrm{L})$.

Some studies have sought to standardize the sensitivity range of potassium dichromate for these species, varying with exposure time and the life stage of the organisms (Cruz et al., 2008; Bertoletti, 2009). The results found by these authors were varied, which can be explained because sensitivity is an intrinsic factor of each organism and is directly associated with the genetic characteristics of the individual, resulting in variations in the findings between laboratories and even within a single brood.

Considering the average $\mathrm{LC}_{50}$; $96 \mathrm{~h}$ for C. xanthus (greater than $1440.0 \mathrm{mg} / \mathrm{kg} ; 340.56 \mathrm{mg} / \mathrm{kg}$ ) in SIII and S0, respectively, it was possible to observe that in SIII the chromium concentration in the water was from 5 to 20 times lower. Furthermore, the concentration of bioavailable chromium in the sediments was some 5 times higher in S0, demonstrating the influence of low MO concentrations on the bioavailability of chromium and thus on its toxicity. These results show that chromium has different effects in this system because of the various forms of interaction of the organisms with the medium (fishes and benthic organisms).

Benthic organisms, such as Chironomidae larvae, are burrowers (Bird et al., 1995) and because they feed on detritus, the metal in the particles poses a high exposure risk (Martinez et al., 2003). However, the physical and chemical conditions in the digestive tract of these organisms can change the toxicity of the metal (Tessier and Campbell,1987). Besides this, the uptake of metals by benthic organisms can result from exposure to interstitial and surface water as well (Lee et al., 2000).

Fish species, on the other hand, interact with the contaminant directly from the compounds dissolved in the water or particles ingested while feeding by contact with the sediment. Fishes of the Poeciliidae and Cyprinidae families are omnivores and the Poeciliidae can also feed on detritus (Meffe and Snelson Junior, 1989). The differences in the sensitivity of organisms can thus be a reflection of the different ways of interacting with the contaminated medium (Baudo et al., 1990).

The acute toxicity of chromium to C.xanthus, $D$. rerio and $P$. reticulata was reduced with the presence of biodegradable OM detritus, even at low concentrations (1\%) and demonstrated that the artificial sediments with simple formulations tested here were adequate to assess the toxicity of chromium. Because of the ease of preparation, the repeatability of experiments and the satisfactory results in the toxicity assessment, artificial sediments with the specifications used in this study should be used more often in laboratory studies to investigate the toxicity of chemical substances and may contribute to the establishment of standardization for such an experiment.

\section{Acknowledgments}

This study received funding from the National Council for Scientific and Technological Development (CNPq), process no. 479135/2006-1.

\section{References}

ADAMS, WJ. 1995. Aquatic Toxicology Testing Methods. In HOFFMAN, DJ., RATTNER, BA., BURTON JUNIOR, GA. and CAIRN JUNIOR, J., orgs. Handbook of Ecotoxicology. Boca Raton: Lewis Publishers. p. 25-46.

AHNSTROM, ZS. and PARKER, DR. 1999. Development and assessment of a sequential extraction procedure for the fractionation of soil cadmium. Soil Science Society of America Journal, vol. 63, p. 1650-1658. http://dx.doi.org/10.2136/ sssaj1999.6361650x

ALOMARY, AA. and BELHADJ, S. 2007. Determination of heavy metals (Cd, Cr, Cu, Fe, Ni, Pb, Zn) by ICP$\mathrm{OES}$ and their speciation in Algerian Mediterranean Sea sediments after a five-stage sequential extraction procedure. Environmental Monitoring and Assessment, vol. 135, p. 265-280. PMid:17342430. http://dx.doi. org/10.1007/s10661-007-9648-8

American Public Health Association - APHA. 1995. American water work association; Water control federation. Standard methods for the examination of the water and wastewater. New York.

Associação Brasileira de Normas Técnicas - ABNT. 2004. NBR 15088: Ecotoxicologia Aquática - Toxicidade aguda - método de ensaio com peixes. São Paulo.

BAUDO, R., GIESY, JP. and MUNTAU, H. 1990. Sediments: chemistry and toxicity of in-place pollutants. Boca Raton: Lewis Publishers, Inc. 405 p. 
BERTOLETTI, E. 2009. Determinação da ecotoxicidade crônica para Danio rerio. Journal of the Brazilian Society of Ecotoxicology, vol. 4, p. 1-7. http://dx.doi. org/10.5132/jbse.2009.01.001

BIRD, GA., ROSENTRETER, MJ. and SCHWARTZ, WJ. 1995. Deformities in the menta of chironomid larvae from the Experimental Lakes Area, Ontario. Canadian Journal of Fisheries and Aquatic Sciences, vol. 52, p. 2290-2295. http://dx.doi.org/10.1139/ f95-819

BRINGOLF, BR., MORRIS, BA., BOESE, CJ., SANTORE, RC., HERBERT, AE. and MEYER, JS. 2006. Influence of Dissolved Organic Matter on Acute Toxicity of Zinc to Larval Fathead Minnows (Pimephales promelas). Archives of Environmental Contamination and Toxicology, vol. 51, p. 438-444. PMid:16788742. http://dx.doi.org/10.1007/ s00244-005-0088-6

BROOKS, ML., MEYER, JS. and BOESE, CJ. 2007. Toxicity of copper to larval Pimephales promelas in the presence of photodegraded natural dissolved organic matter. Canadian Journal of Fisheries and Aquatic Sciences, vol. 64, p. 391-401. http://dx.doi. org/10.1139/f07-012

BURTON, GL. and MacPHERSON, C. 1994. Sediment toxicity testing issue and methods. In HOFFMAN, DJ., RATTNER, BA., BURTON JUNIOR, GA. and CAIRN JUNIOR, J., orgs. Handbook of ecotoxicology. Boca Raton: Lewis Publishers. p. 70-103.

CEURDASSIER, M., VAUfLEURY, AG and DE BADOT, PM. 2000. Dose-dependent growth inhibition and bioaccumulation of hexavalent chromium in land snail helix Aspersa aspersa. Environmental Toxicology and Chemistry, vol. 19, p. 2571-2578.

CHOI, J. and ROCHE, H. 2004. Effect of potassiumdichromate and fenitrothion on hemoglobins of Chironomus riparius MG. (Diptera, Chironomidae) larvae: potential biomarker of environmental monitoring. Environmental Monitoring and Assessment, vol. 92, p. 229-239. PMid:15038546. http://dx.doi.org/10.1023/ B:EMAS.0000014503.23761.77

CLÉMENT, B. and CADIER, C. 1998. Development of a new laboratory/sediment microcosm test. Ecotoxicology, vol. 7, p. 279-280. http://dx.doi. org/10.1023/A:1008868330206

CRUZ, C., CUBO, P., GOMES, GR., VENTURINI, FP., GUILHERME, PE. and PITELLI, RA. 2008. Sensibilidade de peixes tropicais ao dicromato de potássio. Journal of the Brazilian Society of Ecotoxicology, vol. 3, no. 1, p. 53-55. http://dx.doi. org/10.5132/jbse.2008.01.008

DAVE, G., DAMGAARD, B., GRANDE, M., MARTELIN, JR., ROSANDER, B. and VIKTOR, T. 1987. Ring test of an embryo-larval toxicity test with zebrafish (Brachydanio rerio) using chromium and zinc as toxicants. Environmental Toxicology and Chemistry, vol. 6, p. 61-71. http://dx.doi. org/10.1002/etc. 5620060108

DE LAUNE, RD., PATRICK, WH. and GUO, T. 1998. The redox-ph chemistry of chromium in water and sediment. In ALLEN, HE., GARRISON, AW. and LUTHER, GW. (Orgs.). Metals in Surface Waters. AnnArbor: Chelsea. p. 241-255.

DOIG, LE. and LIBER, K. 2006. Nickel partitioning in formulated and natural freshwater sediments. Chemosphere, vol. 62, p. 968-979. PMid:16122779. http://dx.doi.org/10.1016/j. chemosphere.2005.06.016

EDWARDS, PA. and SIMKISS, K. 2005. Dietary Influences on the Bioaccumulation of Pollutants by the Annelid, Lumbriculus variegatus: Experiments Comparing Artificial Particles and Natural Sediments. Bulletin of Environmental Contamination and Toxicology, vol. 74, p. 328-334. PMid:15841974. http://dx.doi.org/10.1007/s00128-004-0588-5

EIMERS, MC., EVANS, RD. and WELBOURN, PM. 2002. Partitioning and bioaccumulation of cadmium in artificial sediment systems: application of a stable isotope tracer technique. Chemosphere, vol. 46, p. 543-551. http://dx.doi.org/10.1016/ S0045-6535(01)00156-4

Embrapa. 2000. Indicadores Biológicos de Bioquímicos da qualidade do solo. Manual Técnico. $35 \mathrm{p}$.

Environmental Protection Agency - EPA. 1996. Method 3052: Microwave Assisted Acid Digestion of Siliceous and Organically based Matrices. Washington Environmental Protection Agency.

FEILER, U., KIRCHESCH, I. and HEININGER, P. 2004. A new plant-based bioassay for aquatic sediments. Journal of Soils and Sediments, vol. 4, p. 261-266. http://dx.doi.org/10.1007/BF02991122

FONSECA, AL. and ROCHA, O. 2004. Laboratory cultures of the native species Chironomus xanthus Rempel, 1939 (Diptera-Chironomidae). Acta Limnologica Brasiliensia, vol. 16, no. 2, p. 153-161.

FÖRSTNER, U. 1987. Sediment-associated contaminants - an overview of scientific bases for developing remedial options. Hydrobiologia, vol. 149, p. 221-246. http://dx.doi.org/10.1007/BF00048663

HAMILTON, MA., RUSSO, RC. and THURSTON, RU. 1977. Trimmed Sperman-Karber method for estimating median lethal concentration in toxicity bioassays. Environmental Science \& Technology, vol. 11, no. 7, p. 714-719. http://dx.doi.org/10.1021/ es60130a004

JOP, KM., PERKERTON, TF., RODGERS JUNIOR, JH. and DICKSON, KL. 1987. Comparative toxicity and speciation of two hexavalent chromium salts in acute toxicity tests. Environmental Toxicology and Chemistry, vol. 6, p. 697-703. 
KEMBLE, NE., DWYER, FJ., INGERSOLL, CG., DAWSON, TD. and NORBERG-KING, T. 1999. Tolerance of freshwater test organisms to formulated sediments for use as control materials in wholesediment toxicity tests. Environmental Toxicology and Chemistry, vol. 2, p. 222-230.

LEE, BG., LEE, JS., LUOMA, SN., CHOI, HJ. and $\mathrm{KOH}, \mathrm{CH}$. 2000. Influence of acid volatile sulfide and metal concentrations on metal bioavailability to marine invertebrates in contaminated sediments. Environmental Science \& Technology, vol. 34, p. 4517 4523. http://dx.doi.org/10.1021/es001033h

MARTINEZ, EA., MOORE, BC., SCHAUMLOFFEL, J. and DASGUPTA, N. 2003. Morphological abnormalities in Chironomus tentans exposed to cadmium-and copper-spiked sediments. Ecotoxicology and Environmental Safety, vol. 55, p. 204-212. http://dx.doi.org/10.1016/S01476513(02)00136-7

MEFFE, GK. and SNELSON JUNIOR, FF. 1989. Ecology and Evolution of livebeatring fishes (Poeciliidae). New Jersey: Prentice Hall. 452 p.

NAKAGOME, FK., NOLDIN, JA. and RESGALLA JUNIOR, C. 2007. Toxicidade aguda de alguns herbicidas e inseticidas utilizados em lavouras de arroz irrigado sobre o peixe Danio rerio. Pesticidas: Revista de Ecotoxicologia e Meio Ambiente, vol. 17, p. 117-122.

NAKAYASU, K., FUKUSHIMA, M., SASAKI, K., TANAKA, S. and NAKAMURA, H. 1999. Comparative studies of the reduction behavior of chromium (VI) by humic substances and their precursors. Environmental Toxicology and Chemistry, vol. 18 , no. 6 , p. 1085-1090.

NAYLOR, C. and RODRIGUES, C. 1995. Development of a test method for Chironomus riparius using a formulated sediment. Chemosphere, vol. 31, no. 5, p. 3291-3303. http://dx.doi.org/10.1016/00456535(95)00178-B

Organization for Economic Co-operation and Development - OECD. 2004. Guidelines for testing of chemicals. $21 \mathrm{p}$.

RIBEIRO, R., KELLY, LA., GONÇALVES, F., BURTON JR, GA. and SOARES, AMVM. 1999. New artificial sediment for Chironomus riparius toxicity testing. Bulletin of Environmental Contamination and Toxicology, vol. 63, p. 691-697. PMid:10594141. http://dx.doi.org/10.1007/s001289901035

ROMAN, YE., DE SCHAMPHELAERE, KAC., NGUYEN, LTH. and JANSSEN, CR. 2007. Chronic toxicity of copper to five benthic invertebrates in laboratory-formulated sediment: Sensitivity comparison and preliminary risk assessment. Science of the Total Environment, vol. 387, p. 128-140. PMid:17631947. http://dx.doi.org/10.1016/j. scitotenv.2007.06.023
SAVVIDES, C., PAPADOPOULOS, A., HARALAMBOUS, KJ. and LOIZIDOU, M. 1995. Sea sediments contaminated with heavy metals: Metal speciation and removal. Water Science and Technology, vol. 32, p. 65-73. http://dx.doi.org/10.1016/02731223(96)00077-7

SCHWERTMANN, U. 1964. Soil iron oxides minerals distinction by photochemical extraction using ammonium oxalate solution. Zeitschrift Pflanzenernähr Düng Bodenkd, vol. 105, p. 194-202. (in Germany with English abstract). http://dx.doi. org/10.1002/jpln.3591050303

SILVA, CSDA. and PEDROZO, MFM. 2001. Ecotoxicologia do cromo e seus compostos. Caderno de Referência Ambiental, vol. 5.

SILVEIRA, MLA., ALLEONI, LRF., O'CONNOR, GA. and CHANG, AC. 2006. Heavy metal sequential extraction methods - a modification for tropical soils. Chemosphere,v. 64 , p. 1929-1938. PMid:16487572. http://dx.doi.org/10.1016/j. chemosphere.2006.01.018

SILVEIRA, ML., ALLEONI, LRF. and CHANG, A. 2008. Condicionadores químicos de solo e retenção e distribuição de cádmio, zinco e cobre em Latossolos tratados com biossólido. Revista Brasileira de Ciência do Solo, vol. 32, p. 1087-1098. http:// dx.doi.org/10.1590/S0100-06832008000300017

SILVERIO, PF., NASCIMENTO, MRL. and MOZETO, AA. 2006. Valores-guia de qualidade de sedimentos de ambientes aquáticos continentais e valores de referência de metais e metalóides. In MOZETO, AA., UMBUZEIRO, GA. and JARDIM, WF., orgs. Métodos de coleta, análises físico-químicas e ensaios biológicos e ecotoxicológicos de sedimentos de água doce. São Carlos: Cubo Multimidia. 221 p.

SKOGERBOE, RK. and WILSON, SA. 1981. Reduction of ionic species by fulvic acid. Analytical Chemistry, vol. 53, p. 228-232. http://dx.doi.org/10.1021/ ac00225a023

SOARES, HMVM., BOAVENTURA, RAR., MACHADO, AASC. and SILVA, JCGE. 1999. Sediments as monitors of heavy metal contamination in the Ave River Basin (Portugal): Multivariate analysis of data. Environmental Pollution, vol. 105, p. 311-323. http://dx.doi.org/10.1016/S02697491(99)00048-2

STEVENS, DG. and CHAPMAN, GA. 1984. Toxicity of trivalent chromium to early life stages of steelhead trout. Environmental Toxicology and Chemistry, vol. 3, p. 125-133. http://dx.doi.org/10.1002/ etc. 5620030114

SUEDEL, BC. and RODGERS, JH. 1994. Development of formulated reference sediments for freshwater and estuarine sediment testing. Environmental Toxicology and Chemistry, vol. 13, p. 1163-1175. http://dx.doi. org/10.1897/1552-8618(1994)13[1163:DOFRSF ]2.0.CO;2 
SVECEVICIUS, G. 2006. Acute toxicity of hexavalent chromium to European freshwater fish. Bulletin of Environmental Contamination and Toxicology, vol. 77, p. 741-747. PMid:17177004. http://dx.doi. org/10.1007/s00128-006-1126-4

SVECEVICIUS, G. 2007. Avoidance response of rainbow trout Oncorhynchus mykiss to hexavalent chromium solutions. Bulletin of Environmental Contamination and Toxicology, vol. 79, p. 596-600.

TESSIER, A. and CAMPBELL, PGC. 1987. Partitioning of trace metals in sediments: Relations with bioavailability. Hidrobiologia, vol. 149, no. 1, p. 43-52. http://dx.doi.org/10.1007/BF00048645

VEDAMANIKAM, VJ. and SHAZILLI, NAM. 2008. Comparative toxicity of nine metals to two Malaysian aquatic dipterian larvae with reference to temperature variation. Bulletin of Environmental Contamination and Toxicology, vol. 80, p. 516-520. PMid:18414763. http://dx.doi.org/10.1007/s00128-008-9413-x
VERRHIEST, GJ., CORTES, S., CLÉMENT, BC. and MONTUELLE, B. 2002. Chemical and bacterial changes during laboratory conditioning of formulated and natural sediments. Chemosphere, vol. 46, p. 961-974. http://dx.doi.org/10.1016/ S0045-6535(01)00187-4

VILLAESCUSA, I., MARTI, S., MATAS, C., MARTINEZ, M. and RIBÓ, JM. 1997. Chromium(vi) toxicity to luminescent bactéria. Environmental Toxicology and Chemistry, vol. 16, p. 871-874. http://dx.doi.org/10.1002/ etc. 5620160506

WANG, F., TESSIER, A. and HARE, L. 2001. Oxygen measurements in the burrows of freshwater insects. Freshwater Biology, vol. 46, p. 317-327. http://dx.doi. org/10.1046/j.1365-2427.2001.00678.x

WITTBRODT, PR. and PALMER, CD. 1995. Reduction of Cr (VI) in the presence of excess soil fulvic acid. Environmental Science \& Technology, vol. 29, p. 255-263. PMid:22200228. http://dx.doi. org/10.1021/es00001a033

Received: 11 January 2012 Accepted: 10 June 2013 